\title{
Serology for Neosporosis, Q fever and Brucellosis to assess the cause of abortion in two dairy cattle herds in Ecuador
}

Darwin Changoluisa', Ismar A. Rivera-Olivero², Gustavo Echeverria ${ }^{3}$, Miguel Angel Garcia-Bereguiain 1,2* (D), Jacobus H. de Waard ${ }^{1,2^{*}}$ and the working group "Applied Microbiology" of the School of Biological Sciences and Engineering at Yachay Tech University ${ }^{1,4}$

\begin{abstract}
Background: Determining the infectious cause of abortion in cattle is difficult. This case-control study was set up to investigate the infectious causes of abortion by determining the seroprevalence of three reproductive pathogens in dairy cattle in Ecuador and their association with abortion: Brucella abortus, Neospora caninum and Coxiella burnetii.

Results: Ninety-five blood samples were obtained from cows that had experienced a mid- or late gestation abortion of their first calf and seventy-seven samples from a control group of cows with the same age that did not experience abortion problems. No antibodies were detected for B. abortus in any of the serum samples, but a high seroprevalence for both C. burnetii (52.9\%) and $N$. caninum infection (21.5\%) was found in group of cows. The seroprevalence of $N$. caninum infection in cattle that had experienced abortions was significantly higher $(p<0.05)$ than the seroprevalence in the control cows on one of the cattle farms, but no association between abortion and seropositivity for $C$. burnetii was found.
\end{abstract}

Conclusion: We conclude that Neosporosis plays an important role in the epidemiology of abortion on one cattle farm, but that $Q$ fever is apparently not an important cause for abortion in this setting.

Keywords: Neosporosis, Neospora, Q fever, Coxiella, Brucellosis, Brucella, Cattle, Ecuador

\section{Background}

Abortion in cattle is defined as the premature expulsion of the fetus between day 50 and day 270 of gestation. Most cattle herds suffer an abortion rate of $1-2 \%$ and it has been suggested that an annual abortion rate up to $5 \%$ is considered normal [1]. In general, the percentage of abortion cases for which a definitive diagnosis is made is very low. For example, in Great Britain less than one third of abortion cases are submitted to the laboratory for diagnosis [1]. In developing countries, this percentage is probably much lower and people usually have no intention of seeking a diagnosis, rather cows that have aborted are culled.

\footnotetext{
*Correspondence: magbereguiain@gmail.com; jacobusdeward@gmail.com ${ }^{1}$ School of Biological Sciences and Engineering, Yachay Tech University, Urcuquí, Ecuador

${ }^{2}$ One Health Research Group, Facultad de Ciencias de la Salud, Universidad de las Américas, Quito, Ecuador

Full list of author information is available at the end of the article
}

Abortions cause significant economic loss, especially those occurring during the last stage of pregnancy. Estimates of the cost of an abortion to a producer range from $\$ 90$ to $\$ 1900$, depending on the gestation phase in which it occurs. A midterm abortion costs the producer between $\$ 600$ and $\$ 1000$ [2]. Costs include those associated with establishing the diagnosis, re-breeding cows that aborted, sperm or embryo costs, possible loss of milk yield and replacement costs if cows that have aborted are culled.

Determining the cause of abortion in cattle is difficult and a major challenge to the herd owner and veterinarian. Infectious agents represent the leading etiology and the majority of diagnosed abortions are attributed to infections with the bacteria Brucella abortus and Leptospira interrogans, the protozoa Neospora caninum and two viruses: Infectious Bovine Rhinotracheitis or bovine herpesvirus (IBR or BHV) and Bovine Viral Diarrhoea

(C) The Author(s). 2019 Open Access This article is distributed under the terms of the Creative Commons Attribution 4.0 International License (http://creativecommons.org/licenses/by/4.0/), which permits unrestricted use, distribution, and 
(BVD) [3]. Moreover, Coxiella burnetii, the causal agent of Q fever which is a zoonotic disease, has been related to stillbirth, aborted fetuses and the delivery of weak and nonviable neonates in ruminants. Yet, the correlation between Coxiella seropositivity and abortion risk in bovines is far less understood $[4,5]$.

Few reports concerning the infectious cause of abortion have been carried out in Latin America and this paper aims to assess the infectious agent that induces abortion in two dairy herds, each of about 2000 heads, from a tropical region of Ecuador. These cattle herds have an annual abortion rate of between 3 and $5 \%$.

In a case-control study and using commercially available ELISAs, we determined the seroprevalence for Brucellosis, Neosporosis and Q fever in cattle that had experienced an abortion during mid- to late gestation. We compared this prevalence with the seroprevalence in a randomly-selected control group of cattle from the same cattle farms and of the same age that had never suffered an abortion and we determined if one of the aforementioned cattle diseases could be associated with abortion.

Brucellosis is endemic in Ecuador and studies have reported a seroprevalence of up to $17 \%$ and a herd prevalence of $45 \%$ [6]. Concerning the infection with C. burnetii in Ecuador, few data are available and a within-herd seroprevalence of more than $40 \%$ and a herd prevalence of $47 \%$ have been reported $[7,8]$. Neosporosis has never been studied in this country, hence the prevalence of this infestation in cattle is unknown. All three diseases are on the World Organization of Animal Health's (OIE) list of notifiable diseases. Ecuador has reported the presence of Brucellosis in its territory to the OIE, but no official reports concerning $\mathrm{Q}$ fever and Neosporosis have been emitted [9].

\section{Results}

A total of 172 cows from two dairy farms- 93 cows from farm A and 79 cows from farm B - were tested with commercially available ELISAs for the presence of antibodies against Brucellosis, Q fever and Neosporosis. The results of the serodiagnosis are summarized in Table 1. In both cattle herds, no antibodies against $B$. abortus were detected and the results for Brucellosis testing were omitted from this table. The overall seroprevalence of $\mathrm{Q}$ fever and Neosporosis were 52.9 and $21.5 \%$, respectively. The prevalence of $\mathrm{Q}$ fever was $49.4 \%$ in cows with a first-calf abortion and 57\% in the control cows and that of Neosporosis, 28.4 and 13.0\%, respectively. Mixed infections with $C$. burnetii and $N$. caninum were also common ( $n=20$ or $11.6 \%)$ with $14(14.7 \%)$ mixed infections in the cows that had a history of abortion and $6(7.8 \%)$ mixed infections in the control group.

A statistical analysis of prevalence rates for the cows from both cattle farms showed a positive association between $N$. caninum infection and abortion (Odds Ratio [OR] 2.66; [CI95\% 1. 19-5.92]; $p=0.014$ ) while no significant association between $C$. burnetii infection and abortion was found (Odds Ratio [OR] 0.73; [CI95\% $0.40-1.34] ; p=0.316$ ). Furthermore, no association between the presence of both infections ( $Q$ fever and Neosporosis) and abortion was found (Odds Ratio [OR] 2.04; [CI95\% 0.74-5.60]; $p=0.158$ ).

When both farms were analyzed separately, on Farm A a positive association between $N$. caninum infection and abortion was found once more (Odds Ratio [OR] 3.84; [CI 95\% 1.295 3- 11.3844]; $p=0.012$ ), but on farm B no association between the presence of $\mathrm{Q}$ fever and/or Neosporosis and abortion was found $(p>0.05)$.

\section{Discussion}

Relatively few studies have been performed in Latin America regarding the cause of abortion in cows and most studies come from Brazil. In Ecuador, the cause of abortion in cows is mostly unexplored. In South America, the most assessed infectious diseases as the cause of abortion are Neosporosis and Brucellosis. To the best of our knowledge, no reports exist on this continent evaluating the burden of Q-fever.

The aim of our study was to find an infectious cause for first-calf abortion in two cattle farms in a tropical part of Ecuador, both farms with a relatively "normal" abortion rate of 3-5\%. This case-control study included 95 cows that had aborted once in the second or third stage of gestation and 77 aged-matched control cows without a history of abortion. In our study, we used commercial ELISA kits to determine the presence of antibodies against Brucellosis, Q fever or Neosporosis and we looked for an association with abortion. We did not search for antibodies against Leptospira interrogans, IBR or BVD. These two viruses and the five Leptospira serovars are commonly associated with abortion in cattle [10]. However, both farms

Table 1 Serodiagnosis of Q fever and Neosporosis in two cattle farms in Ecuador. We tested cows with a history of a first-calf abortion $(n=95)$ and a control group of cows of the same age group that had never aborted $(n=77)$

\begin{tabular}{lllll}
\hline Cows tested & $\begin{array}{l}\text { Cows that aborted } \\
\text { Q fever }+\end{array}$ & $\begin{array}{l}\text { Control cows } \\
\text { Q fever }+\end{array}$ & $\begin{array}{l}\text { Cows that aborted } \\
\text { Neosporosis }+\end{array}$ & $\begin{array}{l}\text { Control cows } \\
\text { Neosporosis }+\end{array}$ \\
\hline Farm A & $34(60.7 \%)$ & $22(59.5 \%)$ & $21(37.5 \%)$ & $5(13.5 \%)$ \\
Farm B & $13(33.3 \%)$ & $22(55.0 \%)$ & $6(15.4 \%)$ & $5(12.5 \%)$ \\
Total $=172$ & $47(49.4 \%)$ & $44(57.1 \%)$ & $27(28.4 \%)$ & $10(13.0 \%)$ \\
\hline
\end{tabular}


vaccinate their cattle with the combination vaccine Cattlemaster ${ }^{\circ}$ GoldFP $^{\circ} 5$ L5 against said viruses and the Leptospira interrogans serovars: grippotyphosa, pomona, hardjo, canicola and icterohaemorrhagiae. Vaccination-induced antibodies against these microorganisms are to be expected in all the cattle under study.

Concerning Brucellosis, although there is an ongoing vaccination program on both cattle farms with the vaccine strain RB51, we tested for Brucellosis antibodies because the disease is highly endemic in Ecuador. Moreover, we recently detected that a dog on one of the cattle farms was positive for Brucella abortus. (Personal communication JHdW, MG) and a previous study determined that the efficacy of the vaccination with RB51 is only partial, preventing approximately $60 \%$ of the cows and fetuses from infection [11]. We therefore cannot exclude infection with $B$. abortus as a cause of abortion, but no seropositive animals were detected in these cattle herds and thus we exclude abortion due to Brucellosis.

It is generally accepted that chronic infection with C. burnetii may cause abortion, premature birth, stillbirth or weak offspring in cattle, sheep and goats [12]. The infection rate we found on both cattle farms was high (49\%), however in our study no association between $\mathrm{Q}$ fever and abortion could be established. In some publications, a strong association has been found between $C$. burnetii infection and abortion [13]. 22\% [14] of abortion cases in a study in Italy and and 37\% [15] of one in Cyprus were due to an infection with $C$. burnetii. In another study, seroprevalence for $\mathrm{Q}$ fever was found to be twice as high in cows that had aborted in comparison with an aged-matched control group [16]. However, our findings support the conclusions of a review on $\mathrm{Q}$ fever that $C$. burnetii infection is an infrequent cause of abortion in cattle [17].

Neospora caninum is considered one of the most frequent infectious organisms causing abortion in cattle worldwide $[18,19]$. Concerning South America, a review of the year 2005 reports evidence of exposure to N. caninum in cattle, goats, sheep, dogs, cats, water buffaloes, alpacas, llamas, opossums, wolves and other wild canids from Argentina, Brazil, Chile, Paraguay, Peru and Uruguay [20].

Here we report, for the first time, the presence of Neosporosis in Ecuador and in this small study, with only 172 cows tested, we found an overall seroprevalence of $21.5 \%$. Blood samples were taken between 2 and 10 months after abortion had taken place and the prevalence of Neosporosis could be even higher in the tested cattle herds because of fluctuations in antibody levels that seemed to be higher just before and after the abortion had taken place [21]. We show that the infection with this parasite on one farm increased the risk of an abortion by a factor of almost 4 . However, on the other cattle farm, no association between seropositivity for $N$. caninum and abortion could be found. No sound explication is readily available to explain the differences between these two cattle farms. Nonetheless, the presence of different $N$. caninum strains on the two cattle farms, that differed in pathogenicity cannot be excluded [22]. In Spain, absence of fetal death has been reported in pregnant heifers inoculated with the NC-Spain-1- H isolate of Neospora caninum, an isolate of low virulence, whereas fetal death occurred in heifers inoculated with the control strain NC1 [23]. The presence of $N$. caninum strains with different virulence could also explains why the two farms in our study had a relatively low abortion rate of 3-5\% in comparison with a relatively high $N$. caninum seroprevalence of $21.5 \%$. Hence, more research is necessary and we have planned to genotype the Neospora strains of our study area. We will also look to directly confirm the presence of $N$. caninum in abortion material or in the fetuses, as was achieved in a study in southern Brazil, where PCR revealed that $38.8 \%$ of the aborted fetuses were positive for $N$. caninum [24].

\section{Conclusions}

We conclude that more investigations, especially on molecular level and DNA analysis for infectious agents in abortion material, is necessary to confirm our observations. In addition, as infection is the most common cause of abortion in cattle, unusual causes should be included in future studies, like Chlamydophila abortus, Salmonella dublin or Listeria monocytogenes infections. In a case-control study, an association between Chlamydia psittaci seropositivity and abortion in Italian dairy cows has been shown [25] but the impact of this microorganism on abortion in South America has never been investigated. Concerning other infectious causes of abortion, bovine venereal diseases, trichomoniasis and genital campylobacteriosis (caused respectively by a protozoan parasite and a gram-negative bacteria) should be included in future studies, as all of them can cause reproductive failure, including repeated estrus, early embryonic death and abortions [26]. To the best of our knowledge, the presence of these diseases has never been studied in Ecuador.

\section{Limitations of this study}

This is a small-scale retrospective study of a limited range of abortifacients on two dairy farms, the first of its kind in Ecuador. Budget constraints did not permit us to study other abortifacients mentioned in the conclusions. In this manuscript, we report that abortifacients, included in the combination vaccine Cattlemaster ${ }^{\circ}$ GoldFP $^{\circ} 5$ L5, were not studied because we expected an antibody response. However, limited public information is available concerning the efficacy of the Cattlemaster vaccine. We therefore will include testing for Leptospirosis and BVD in future investigations and verify if in fact there is association of 
Table 2 Number and average age with standard deviation of cows that aborted their first calves and aged-matched control cows from two cattle farms in Ecuador

\begin{tabular}{lll}
\hline & Cows that aborted and age & Control cows and age \\
\hline Farm $1 \mathrm{~N}_{\mathrm{t}}=93$ & $n=56,35 \pm 6$ months & $n=37,32 \pm 7$ months \\
Farm 2 N $=79$ & $n=39,65 \pm 27$ months & $n=40,72 \pm 33$ months \\
$\mathrm{Nt}=172$ & $\mathrm{n}=95$ & $N=77$ \\
\hline
\end{tabular}

vaccination with serological results, as these are important causes of abortion in cattle.

\section{Methods}

\section{Sample collection}

172 blood samples were collected from two dairy farms in Ecuador. 95 serum samples came from cattle that had aborted in the second and third trimester of their first pregnancy and 77 from cows of a randomly selected control group of the same age but without a history of abortion. For details, see Table 2. The cattle farms are located in Santo Domingo Province, a tropical area of the country. Both dairy cattle herds have about 2000 heads and blood samples were taken at random of approximately $40 \%$ of the cows that had aborted in the year 2018. Blood samples were taken between 2 and 10 months after the abortions had taken place. The herds are maintained as closed herds and in general the cows are artificially inseminated. Both farms have a relatively "normal" abortion rate of $3-5 \%$.

Blood was collected from the tail (coccygeal) vein in a red-top tube with serum clot activator. After clotting was complete, $1 \mathrm{ml}$ of serum was collected and

Table 3 Commercially available ELISA test kits used for detecting antibodies against B. abortus, N. caninum, and C. burnetii. *The sensitivity (Se) and specificity (Sp) of the diagnostic kits were provided by the manufacturer of the kits

\begin{tabular}{|c|c|c|c|c|c|}
\hline $\begin{array}{l}\text { Infectious } \\
\text { Agent }\end{array}$ & ELISA test kit & Manufacturer & Antigens & $\mathrm{Se}^{*}$ & $S p^{*}$ \\
\hline $\begin{array}{l}\text { Brucella } \\
\text { abortus }\end{array}$ & $\begin{array}{l}\text { ID Screen }^{\circledast} \\
\text { Brucellosis } \\
\text { Serum } \\
\text { Indirect } \\
\text { Multi- } \\
\text { species }\end{array}$ & $\begin{array}{l}\text { ID.vet } \\
\text { Innovative } \\
\text { Diagnostics, } \\
\text { Grabels, } \\
\text { France }\end{array}$ & $\begin{array}{l}\text { LPS of } \\
\text { Brucella } \\
\text { abortus }\end{array}$ & $\begin{array}{l}100 \% \\
\text { (IC95\%: } \\
89.57- \\
100 \%)\end{array}$ & $\begin{array}{l}99.74 \% \\
\text { (IC95\%: } \\
99.24- \\
99.91 \%\end{array}$ \\
\hline $\begin{array}{l}\text { Neospora } \\
\text { caninum }\end{array}$ & $\begin{array}{l}\text { ID Screen } \\
\text { Neospora } \\
\text { caninum } \\
\text { Indirect } \\
\text { Multi- } \\
\text { species }\end{array}$ & $\begin{array}{l}\text { ID.vet } \\
\text { Innovative } \\
\text { Diagnostics, } \\
\text { Grabels, } \\
\text { France }\end{array}$ & $\begin{array}{l}\text { Purified } \\
\text { extract of } \\
\text { Neospora } \\
\text { caninum }\end{array}$ & $\begin{array}{l}100 \% \\
\text { (IC95\%: } \\
98.8- \\
100 \%)\end{array}$ & $\begin{array}{l}100 \% \\
\text { (IC95\%) } \\
99.41- \\
100 \%),\end{array}$ \\
\hline $\begin{array}{l}\text { Coxiella } \\
\text { burnetii }\end{array}$ & $\begin{array}{l}\text { ID Screen }{ }^{\oplus} \\
\text { Q fever } \\
\text { indirect } \\
\text { Multi- } \\
\text { species }\end{array}$ & $\begin{array}{l}\text { ID.vet } \\
\text { Innovative } \\
\text { Diagnostics, } \\
\text { Grabels, } \\
\text { France }\end{array}$ & $\begin{array}{l}\text { phase I } \\
\text { and phase } \\
\text { II antigens } \\
\text { Coxiella } \\
\text { burnetii }\end{array}$ & $\begin{array}{l}100 \% \\
\text { (C195\%: } \\
89.28- \\
100 \%)\end{array}$ & $\begin{array}{l}100 \% \\
(\mathrm{Cl} 195 \% \\
97.75- \\
100 \%)\end{array}$ \\
\hline
\end{tabular}

transferred into a cryovial tube and maintained at $4{ }^{\circ} \mathrm{C}$ until used in the ELISAs (max. 2 days).

\section{Serological testing}

All serum samples were tested for antibodies against $C$. burnetii, $N$. caninum, and B. abortus by an enzymelinked immunosorbent assay (ELISA) using commercial test kits and following the manufacturer's instructions. The corresponding values for optical density were recorded by a 96-well microplates reader. Specific details of the ELISA kits, along with the sensitivities and specificities of the assays, are shown in Table 3.

\section{Statistical analysis}

We performed a Chi-square test and a Fisher's exact test analysis to compare the prevalence data of Coxiella burnetii infection and Neospora infection in cows that aborted vs. controls. In addition, we calculated odds ratios (ORs) with 95\% confidence intervals (CIs). The statistical significance was set at $p<0.05$. The data were analyzed using SPSS Version 22.0 for Windows.

\section{Additional file}

Additional file 1: Detailed values for all serological tests for all the subjects included on this study. (XLSX $30 \mathrm{~kb}$ )

\section{Abbreviations}

BHV: Bovine herpesvirus; BVD: Bovine viral diarrhea virus; IBR: Infectious Bovine Rhinotracheitis; OIE: World Organization of Animal Health

\section{Acknowledgements}

We would like to thank the following members of the working group "Applied Microbiology" from the School of Biological Sciences and Engineering at Yachay Tech University, Urcuquí, Imbabura Province, Ecuador that contributed as co-authors to this publication: Sofía Abad-Sojos, María J. Aldáz-Villao, Estefanía Benavides, Carla M. Brito, Angie Changuan, Marlon Chimarro, Nicole Espinosa, Martha Galarraga, Marlon A. Gancino Guevara, Keila Gómez, Cristian Guzmán, Nigel F. Haro Sisa, Henry J. Herrera, Juan C. Laglaguano, Kerly León-Ordóñez, Katherine Loachamin, Karla Miño, Cristhian Preciado, Sebastián Rodríguez, María P. Romero, Karen Sánchez, Henry Secaira-Morocho, Carolina Serrano-Larrea, Jorge E. Simón Tanquero, María E. Sulen, Odalys Torres, Paolo Vallejo-Janeta, Sabrina Yanez, Marlon Zambrano-Mila.

\section{Funding}

None.

\section{Availability of data and materials}

A supplementary file (Additional file 1) with all the data included on the study is available through BMC Vet. Research site.

\section{Authors' contributions}

DC and GE: sample collection; JHdW and MAGB: study design, data collection, manuscript preparation, revision and editing; IRO: Statistical evaluation and manuscript preparation and revision; Applied microbiology group: data collection and manuscript preparation. All authors read and approved the final manuscript.

\section{Ethics approval and consent to participate}

According to national regulations in Ecuador, the need for ethics approval is unnecessary for sample collection for the diagnosis of farm animals ("Ley Orgánica de Sanidad Agropecuaria" 2017, Asamblea Nacional, República del 
Ecuador). Written informed consent was obtained from the cattle owner who was informed of the results of this investigation.

\section{Consent for publication}

Written informed consent was obtained from the cattle owner who was informed of the results of this investigation and authorized publication of the data.

\section{Competing interests}

The authors declare that they have no competing interests.

\section{Publisher's Note}

Springer Nature remains neutral with regard to jurisdictional claims in published maps and institutional affiliations.

\section{Author details}

${ }^{1}$ School of Biological Sciences and Engineering, Yachay Tech University, Urcuquí, Ecuador. ${ }^{2}$ One Health Research Group, Facultad de Ciencias de la Salud, Universidad de las Américas, Quito, Ecuador. ${ }^{3}$ Instituto de Investigacion en Salud Publica y Zoonosis, CIZ, Universidad Central del Ecuador, Quito, Ecuador. "The working group "Applied Microbiology", School of Biological Sciences and Engineering, Yachay Tech University, Urcuquí, Ecuador.

Received: 18 January 2019 Accepted: 17 May 2019

Published online: 11 June 2019

\section{References}

1. Laven, R. Dealing with abortion. NADIS. National Animal Disease Information Service Available at http://www.nadis.org.uk/disease-a-z/cattle/fertility-indairy-herds/part-6-dealing-with-abortion/. Accessed 28 Nov 2018.

2. Peter AT. Abortions in dairy cows: new insights and economic impact. Adv Dairy Technol. 2000;12:233.

3. Hovingh E. Abortions in dairy cattle: I. Common causes of abortions. In: Virginia Coop. Ext. Publ. Blacksburg: Virginia Polytechnic Institute and State University; 2009. p. 404-288. Available: http://www.holsteinusa.com/pdf/ haplotypes_affe cting_fertility_080511.pdf

4. Garcia-Ispierto I, Tutusaus J, López-Gatius F. Does Coxiella burnetii affect reproduction in cattle? A clinical update. Reprod Domest Anim. 2014;49(4):529-35.

5. Angelakis E, Raoult D. Q fever. Vet Microbiol. 2010;140(4):297-309.

6. Carbonero A, Guzmán LT, García-Bocanegra I, Borge C, Adaszek L, Arenas A, Saa LR. Seroprevalence and risk factors associated with Brucella seropositivity in dairy and mixed cattle herds from Ecuador. Trop Anim Health Prod. 2018;50(1):197-203.

7. Echeverría G, Reyna-Bello A, Minda-Aluisa E, CeliErazo M, Olmedo L, García HA, Garcia-Bereguiain MA, de Waard JH, and the UNU/BIOLAC network for infectious cattle diseases. Serological evidence of Coxiella burnetii infection in cattle and farm workers in Ecuador; is Q fever an under-reported zoonotic disease? Infect Drug Resist. 2019;12:701-6.

8. Carbonero A, Guzmán LT, Montaño K, Torralbo A, Arenas-Montes A, Saa LR. Coxiella burnetii seroprevalence and associated risk factors in dairy and mixed cattle farms from Ecuador. Prev Vet Med. 2015;118(4):427-35.

9. OIE-Listed diseases, infections and infestations in force in 2018. Available at http://www.oie.int/animal-health-in-the-world/oie-listed-diseases-2018/. Accessed 28 Nov 2018

10. Grooms DL, Bolin CA. Diagnosis of fetal loss caused by bovine viral diarrhea virus and Leptospira spp. Vet Clin North Am Food Anim Pract. 2005;21(2): 463-72 Review.

11. Poester FP, Gonçalves VS, Paixão TA, Santos RL, Olsen SC, Schurig GG, Lage AP. Efficacy of strain RB51 vaccine in heifers against experimental brucellosis. Vaccine. 2006;24(25):5327-34

12. Q fever. OIE Terrestrial manual 2018, Chapter 2.1.16. World Organization for Animal Health. http://www.oie.int/fileadmin/Home/eng/Health_standards/ tahm/2.01.16_Q_FEVER.pdf. Accessed 28 Nov 2018.

13. Vidal S, Kegler K, Greub G, Aeby S, Borel N, Dagleish MP, Posthaus H, Perreten V, Rodriguez-Campos S. Neglected zoonotic agents in cattle abortion: tackling the difficult to grow bacteria. BMC Vet Res. 2017;13(1):373.

14. Parisi A, Fraccalvieri R, Cafiero M, Miccolupo A, Padalino I, Montagna C, Capuano F. Sottili R. Diagnosis of Coxiella burnetii-related abortion in Italian domestic ruminants using single-tube nested PCR. Vet Microbiol. 2006;118:101-6.
15. Cantas H, Muwonge A, Sareyyupoglu B, Yardimci H, Skjerve E. Q fever abortions in ruminants and associated on-farm risk factors in northern Cyprus. BMC Vet Res. 2011;7:13.

16. Cabassi CS, Taddei S, Donofrio G, Ghidini F, Piancastelli C, Flammini CF, Cavirani S. Association between Coxiella burnetii seropositivity and abortion in dairy cattle of northern Italy. New Microbiol. 2006;29(3):211-4.

17. Agerholm JS. Coxiella burnetii associated reproductive disorders in domestic animals--a critical review. Acta Vet Scand. 2013;55:13.

18. Shaapan RM. The common zoonotic protozoal diseases causing abortion. J Parasit Dis. 2016:40(4):1116-29.

19. Reichel M, Alejandra Ayanegui-Alcérreca M, Gondim L, Ellis J. What is the global economic impact of Neospora caninum in cattle - the billion dollar question. Int J Parasitol. 2013:43(2):133-42.

20. Moore DP. Neosporosis in South America. Vet Parasitol. 2005;127(2):87-97.

21. Häsler B, Hernandez JA, Reist M, Sager H, Steiner-Moret C, Staubli D, Stärk KDC, Gottstein B. Neospora caninum: serological follow-up in dairy cows during pregnancy. Vet Parasitol. 2006;137:222-30.

22. Calarco L, Barratt J, Ellis J. Genome wide identification of mutational hotspots in the apicomplexan parasite Neospora caninum and the implications for virulence. Genome Biol Evol. 2018;10(9):2417-31.

23. Rojo-Montejo S, Collantes-Fernández E, Blanco-Murcia J, Rodríguez-Bertos A, Risco-Castillo V, Ortega-Mora LM. Experimental infection with a low virulence isolate of Neospora caninum at 70 days gestation in cattle did not result in foetopathy. Vet Res. 2009;40(5):49.

24. Macedo CAB, Macedo MFSB, Miura AC, Taroda A, Cardim ST, Innes EA, Katzer F, Cantón GJ, Chianini F, Headley SA, Garcia JL. Occurrence of abortions induced by Neospora caninum in dairy cattle from Santa Catarina, southern Brazil. Rev Bras Parasitol Vet. 2017;26(3):292-8.

25. Cavirani S, Cabassi CS, Donofrio G, De laco B, Taddei S, Flammini CF. Association between chlamydia psittaci seropositivity and abortion in Italian dairy cows. Prev Vet Med. 2001;50(1-2):145-51.

26. Michi AN, Favetto PH, Kastelic J, Cobo ER. A review of sexually transmitted bovine trichomoniasis and campylobacteriosis affecting cattle reproductive health. Theriogenology. 2016;85(5):781-91.

Ready to submit your research? Choose BMC and benefit from:

- fast, convenient online submission

- thorough peer review by experienced researchers in your field

- rapid publication on acceptance

- support for research data, including large and complex data types

- gold Open Access which fosters wider collaboration and increased citations

- maximum visibility for your research: over $100 \mathrm{M}$ website views per year

At $\mathrm{BMC}$, research is always in progress.

Learn more biomedcentral.com/submissions 